\title{
ANALISIS METODE DEPRESIASI DALAM MENENTUKAN LABA PADA USAHA FOTO COPY AYENG KOMPUTER \\ DI MASAMBA
}

\author{
Sri Wahyuni Mustafa ${ }^{1}$ \\ Hasriani Aripin²
}

No. HP $085299854222^{1}$

\section{ABSTRAK}

Penelitian ini bertujuan untuk mengetahui metode depresiasi dalam menentukan laba pada usaha foto copy Ayeng Komputer di Masamba. Metode analisis depresiasi yang digunakan adalah metode garis lurus yang digunakan untuk menghitung beban penyusutan aktiva tetap dalam mendapatkan laba dimana beban penyusutan konstan pada setiap periode selama masa manfaat dari aktiva tetap yang bersangkutan, metode jumlah angka tahun yang digunakan untuk menentukan seberapa besar laba usaha perhitungan biaya penyusutan didasarkan pada tahun-tahun pemakaian aktiva yang masih tersisa sejak awal tahun hingga tahun pemakaian akhir. Berdasarkan analisis data yang digunakan maka dapat diketahui bahwa penggunaan metode yang digunakan dalam menghasilkan laba selalu mengalami peningkatan setiap tahunnya.

Kata kunci: Usaha Ayeng Komputer, Metode Garis Lurus, Metode Jumlah Angka Tahun

\section{PENDAHULUAN}

Dewasa ini persaingan di dunia usaha sangat ketat, untuk menghadapinya semua pihak yang terlibat di dalamnya harus melakukan kegiatan usahanya secara efektif, artinya pemilik usaha harus mempertahankan hidupnya melalui pencapaian tujuan.

Tujuan suatu usaha adalah agar dapat memperoleh laba yang optimal dari investasi yang telah ditanamkan dalam usahanya. Salah satu investasi tersebut adalah aktiva yang digunakan dalam kegiatan normal perusahaan yaitu aktiva yang mempunyai umur ekonomis lebih dari satu tahun. Untuk mencapainya diperlukan pengelolaan yang efektif dalam penggunaan, pemeliharaan maupun pencatatan akuntansinya.

Untuk meningkatkan produksi yang diharapkan perusahaan harus meningkatkan kualitas yang baik. Dimana keberadaan aktiva memegang peranan yang penting dalam kegiatan operasi perusahaan. Suatu perencanaan yang matang pada saat pengadaan aktiva tetap sangat diperlukan karena berdampak jangka panjang dan berakibat pada kinerja perusahaan. Bila perencanaan pengadaan dan pemeliharaan aktiva tetap kurang baik, maka pada saat masa-masa yang akan datang dapat menyebabkan biaya operasional yang tinggi sehingga akan membebani perusahaan. 
Istilah Depresiasi yang digunakan dalam akuntansi sering kali menyesatkan karena istilah yang sama juga digunakan dalam bisnis untuk menjelaskan penurunan nilai pasar dari suatu aset. Namun, biaya aset yang belum menjadi beban seperti yang dilaporkan dalam neraca biasanya tidak sama dengan jumlah yang bisa dihasilkan dari penjualan aset tetap tersebut. Perusahaan diasumsikan terus menjadi going concern yaitu konsep yang menganggap bahwa suatu kesatuan usaha diharapkan akan terus beroperasi dengan menguntungkan dengan jangka waktu tak terbatas.

Untuk menentukan besarnya aset tetap maka faktor-faktor yang perlu diperhatikan adalah harga perolehan, umur manfaat dan nilai residu/nilai sisa. Setiap perusahaan memiliki kebijakan tersendiri dalam menentukan metode Depresiasi aset tetap yang diterapkan dalam perusahaannya. Perusahaan menggunakan salah satu metode Depresiasi aset tetap akan tetapi dapat juga menggunakan dengan beberapa metode untuk menganalisa perbandingan dari beberapa metode tersebut mana yang lebih menguntungkan atau efektif dan efesien bagi perusahaan yang bersangkutan.

Ketetapan dalam perhitungan dan penentuan metode Depresiasi aset tetap merupakan hal yang sangat penting dalam kegiatan untuk menganalisa perbandingan metode yang digunakan dalam setiap metodenya. Untuk itu, mengingat pentingnya peranan aset tetap didalam laporan keuangan perusahaan,

\section{METODE PENELITIAN}

Lokasi atau tempat penelitian dilakukan pada pada toko Ayeng Komputer yang beralamat di Jl.Simpurusiang Kec. Masamba Kabupaten Luwu Utara. Jenis dan sumber data yang digunakan yaitu Data Primer dan Sekunder. Metode pengumpulan data yang digunakan penelitian langsung dan penelitian kepustakaan. Untuk memecahkan masalah pokok sekaligus membuktikan hipotesis yang diajukan dalam penelitian ini, maka peneliti menggunakan metode analisis komperatif yaitu membandingkan antara beberapa metode penuyusutan dan laporan laba rugi selama 3 tahun yang terdiri dari:

1. Metode Garis lurus (straight-line method).

Beban Penyusutan tiap tahun dapat dihitung dgn rumus:

Beban Penyusutan $=\frac{\text { Harga Perolehan-Nilai Sisa }}{\text { Umur Ekonomis }}$

2. Metode Saldo Menurun

Langkah-langkah perhitungan:

a. Tentukan tarif penyusutan

$$
\text { Tarif }=1-\left(\frac{\mathrm{NS}}{\mathrm{HP}}\right)^{1 / \mathrm{n}}
$$

b. Tentukan Beban Penyusutan

Beban Penyusutan $=$ Tarif $\mathrm{x}$ Nilai Buku Nilai Buku $=$ Harga Perolehan Akumulasi Penyusutan

3. Metode Saldo Menurun Ganda Langkahlangkah perhitungan:

a. Tentukan Tarif penyusutan

$$
\text { Tarif }=2 \times(100 \% / U E)
$$

b. Beban Penyusutan $=$ Tarif $x$ Nilai Buku 
Nilai Buku $=$ Harga Perolehan Akumulasi Penyusutan

4. Jumlah Angka Tahun

Langkah-langkah perhitungan:

a. Tentukan jumlah angka tahun (JAT)

$$
\mathrm{JAT}=\mathrm{nx} \frac{(\mathrm{n}+1)}{2}
$$

b. TentukanBeban Penyusutan

Beban Penyusutan $=\frac{\mathrm{AT}}{\mathrm{JAT}} \times(\mathrm{HP}-$ NS)

\section{HASIL PENELITIAN DAN PEMBAHASAN}

\section{Jenis-Jenis Aktiva Tetap Dalam Perusahaan}

a. Tanah

Tanah merupakan tempat berdirinya usaha.Tanah dalam hal ini tidak mengalami penyusutan maka bila dilihat setiap tahunnya harga perolehan tanah tetap sebesar Rp. 35.000.000.

b. Bangunan

Bangunan merupakan tempat melakukan segala kegiatan operasional usaha. Digunakan dari tanggal 8 Agustus 2008. Harga perolehan bangunan adalah

Rp. 105,000,000.dengan masa manfaat taksiran selama 20 tahun dan nilai sisanya sebesar Rp.20,000,000, Untuk aktiva bangunan masa penggunaannya terbatas. Apabila sudah habis dapat diganti dengan aktiva yang sejenis. c. Inventaris

Inventaris pada usaha foto copy Ayeng Komputer adalah termasuk peralatan dan perlengkapan usaha. Dibeli dan digunakan dari tanggal 8 September 2008. Harga perolehan Mesin Foto copy adalah Rp. 35,000,000, dengan masa manfaat taksiran selama 4 tahun dan nilai sisa sebesar Rp. 10,000,000. Komputer PC dibeli dan digunakan dari tanggal 8 September 2008 dengan harga perolehan adalah Rp. 11,200,000 dengan masa manfaat taksiran selama 4 tahun dan nilai sisa sebesar Rp. 3,000,000, printer dibeli dan digunakan dari tanggal 8 September 2008 dengan harga perolehan adalah $\mathrm{Rp}$. $2,500,000$, dengan masa manfaat taksiran selama 5 tahun dan nilai sisa sebesar Rp.500,000. Meubiler dibeli dan digunakan dari tanggal 8 September 2008 dengan harga perolehan adalah $\mathrm{Rp}$. $45,000,000$, dengan masa manfaat taksiran selama 4 tahun dan nilai sisa sebesar Rp.10,000,000.

\section{Pembahasan Data Hasil Penelitian}

\section{Analisis Metode Depresiasi}

Penelitian ini merupakan penelitian komparatif dimana membandingkan beberapa jenis metode penyusutan aktiva tetap. Yaitu:

a. Metode Garis Lurus (Straight Line Method)

Beban Penyusutan $=\frac{\text { Harga Perolehan-Nilai Sisa }}{\text { Umur Ekonomis }}$ 


\section{Tabel 1}

Akumulasi Beban Penyusutan “Usaha Foto Copy Ayeng Komputer” Melalui metode Garis Lurus dari tahun 2009 - 2013

\begin{tabular}{|c|c|c|c|c|c|}
\hline \multirow{2}{*}{ Jenis Aktiva } & \multicolumn{5}{|c|}{$\begin{array}{c}\text { Beban Penyusutan } \\
(\mathrm{Rp})\end{array}$} \\
\hline & 2009 & 2010 & 2011 & 2012 & 2013 \\
\hline Bangunan & $4,250,0200$ & $4,250,0200$ & $4,250,0200$ & $4,250,0200$ & $4,250,0200$ \\
\hline $\begin{array}{l}\text { Mesin } \\
\text { Fotocopy }\end{array}$ & $6,250,000$ & $6,250,000$ & $6,250,000$ & $6,250,000$ & $6,250,000$ \\
\hline Komputer PC & $2,150,000$ & $2,150,000$ & $2,150,000$ & $2,150,000$ & $2,150,000$ \\
\hline Printer & 500,000 & 500,000 & 500,000 & 500,000 & 500,000 \\
\hline Meubiler & $8,750,000$ & $8,750,000$ & $8,750,000$ & $8,750,000$ & $8,750,000$ \\
\hline $\begin{array}{l}\text { Total Beban } \\
\text { Penyusutan }\end{array}$ & $21,900,000$ & $21,900,000$ & $21,900,000$ & $21,900,000$ & $21,900,000$ \\
\hline
\end{tabular}

Sumber Data : Data diolah

b. Metode Saldo Menurun

Beban Penyusutan tiap tahun dapat dihitung dengan rumus:

Tarif $=1-\left(\frac{\mathrm{NS}}{\mathrm{HP}}\right)^{\frac{1}{n}}$

Kemudian Tentukan Beban Penyusutan
Beban Penyusutan $=$ Tarif $\mathrm{x}$ Nilai Buku

Nilai Buku $=$ Harga Perolehan - Akumulasi Penyusutan 
Tabel 2

Akumulasi Beban Penyusutan “Usaha Foto Copy Ayeng Komputer”Melalui Metode Saldo Menurun dari tahun 2009 - 2013

\begin{tabular}{|c|c|c|c|c|c|}
\hline \multirow{2}{*}{ Jenis Aktiva } & \multicolumn{5}{|c|}{$\begin{array}{c}\text { Beban Penyusutan } \\
\text { (Rp) }\end{array}$} \\
\hline & 2009 & 2010 & 2011 & 2012 & 2013 \\
\hline Bangunan & $8,136,234$ & $7,488,590$ & $8,892,498$ & $6,343,855$ & $5,838,846$ \\
\hline $\begin{array}{l}\text { Mesin } \\
\text { Fotocopy }\end{array}$ & $8,778,812$ & $6,418,189$ & $4,692,330$ & $3,430,569$ & $2,508,089$ \\
\hline Komputer PC & $2,921,295$ & $2,101,872$ & $1,512,297$ & $1,022,096$ & 782,886 \\
\hline Printer & 759,442 & 507,915 & 339,693 & 227,187 & 151,943 \\
\hline Meubiler & $12,998,303$ & $8,924,447$ & $6,127,526$ & $4,207,159$ & $2,888,635$ \\
\hline $\begin{array}{l}\text { Total Beban } \\
\text { Penyosutan }\end{array}$ & $33,594,086$ & $25,442,013$ & $21,564,344$ & $15,230,866$ & $12,170,399$ \\
\hline
\end{tabular}

Sumber Data : Data diolah

c. Saldo Menurun Ganda

Beban Penyusutan tiap tahun dapat

dihitung dengan rumus:

Tentukan Tarif $=2 \times(100 \% / U E)$

Kemudian Beban Penyusutan $=$ Tarif $\mathrm{x}$

Nilai Buku

Nilai Buku = Harga Perolehan -

Akumulasi Penyusutan 
Tabel 3

Akumulasi Beban Penyusutan “Usaha Foto Copy Ayeng Komputer”'Melalui Metode Saldo Menurun Ganda dari tahun 2009 - 2013

\begin{tabular}{||l|r|r|r|r|r||}
\hline \multirow{2}{*}{ Jenis Aktiva } & \multicolumn{5}{|c|}{ Beban Penyusutan } \\
\cline { 2 - 6 } & 2009 & 2010 & 2011 & 2012 & 2013 \\
\hline \hline Bangunan & 10.150 .000 & 9.135 .000 & 8.221 .500 & 7.399 .350 & 6.659 .415 \\
\hline Mesin Fotocopy & $15,312,500$ & $7,656,250$ & $3,828,125$ & $1,914,062$ & 957,031 \\
\hline Komputer PC & $4,900,000$ & $2,450,000$ & $1,225,000$ & 612,500 & 306,250 \\
\hline Printer & $1,093,750$ & & & & \\
\hline
\end{tabular}

Sumber Data : Data diolah

d. Metode Jumlah Angka Tahun

Beban Penyusutan tiap tahun dapat dihitung dengan Langkah-langkah perhitungan:

Tentukan jumlah angka tahun (JAT)

$$
\mathrm{JAT}=\mathbf{n} \mathbf{x} \frac{(\mathbf{n}+\mathbf{1})}{\mathbf{2}}
$$

Setelah penyebutnya diketahui maka besarnya penyusutan tiap tahun dapat dihitung menggunakan rumus:
Beban Penyusutan Tahun I (2009)

$=\frac{A T}{J A T} \times(H P-N S)$

Beban Penyusutan Tahun II (2010)

$$
=\frac{(\mathrm{AT}-1)}{\mathrm{JAT}} \times(\mathrm{HP}-\mathrm{NS})
$$

Beban Penyusutan Tahun III (2011)

$$
=\frac{(\mathrm{AT}-2)}{\mathrm{JAT}} \times(\mathrm{HP}-\mathrm{NS})
$$


Beban Penyusutan Tahun IV (2012)

Beban Penyusutan Tahun IV (2013)

$\frac{(\mathrm{AT}-3)}{\mathrm{JAT}} \mathrm{X}(\mathrm{HP}-\mathrm{NS})$

$=\frac{(A T-3)}{\text { JAT }} \times\left(H P-\frac{N(A) T-4)}{\text { JAT }} \times(H P-N S)\right.$

Tabel 3

\section{Akumulasi Beban Penyusutan “Usaha Foto Copy Ayeng Komputer”Melalui Metode Jumlah Angka Tahun dari tahun 2009 - 2013}

\begin{tabular}{|c|c|c|c|c|c|}
\hline \multirow{2}{*}{ Jenis Aktiva } & \multicolumn{5}{|c|}{ eban Penyusutan (Rp) } \\
\hline & 2009 & 2010 & 2011 & 2012 & 2013 \\
\hline Bangunan & $8,095,238$ & $7,690,468$ & $7,285,707$ & $6,880,945$ & $6,476,618$ \\
\hline $\begin{array}{l}\text { Mesin } \\
\text { Fotocopy }\end{array}$ & $10,000,000$ & $7,500,000$ & $5,000,000$ & $2,500,000$ & 0 \\
\hline Komputer PC & $3,280,000$ & $2,460,000$ & $1,640,000$ & 820,000 & 0 \\
\hline Printer & 800,000 & 600,000 & 400,000 & 200,000 & 0 \\
\hline Meubiler & $14,000,000$ & $10,500,000$ & $7,000,000$ & $3,500,000$ & 0 \\
\hline $\begin{array}{l}\text { Total Beban } \\
\text { Penyusutan }\end{array}$ & $36,175,238$ & $28,750,468$ & $21,325,707$ & $13,900,945$ & $6,478,618$ \\
\hline
\end{tabular}

\section{KESIMPULAN}

1. Berdasarkan analisis data melalui metode Jumlah Angka Tahun beban penyusutan aktiva tetap pada Usaha Foto Copy Ayeng Komputer pada tahun 2009 adalah Rp.36,175,238, pada tahun 2010 sebesar Rp.28,750,468, pada tahun 2011 sebesar
Rp. 21,325,707, pada tahun 2012 sebesar Rp. 13,900,945 dan pada tahun 2013 sebesar Rp. 6,476,618.

2. Dari data di atas dapat dilihat bahwa beban penyusutan aktiva tetap pada Usaha Foto Copy Ayeng Komputer dari tahun 2009 sampai Tahun 2013 yang paling rendah 
didapatkan dengan menggunakan perhitungan beban depresiasi melalui metode garis lurus jika dibandingkan dengan menggunakan metode yang lainnya. Jadi, jika Usaha Foto Copy Ayeng Komputer ingin mendapatkan laba yang besar maka harus menggunakan metode garis lurus tersebut.

3. Berdasarkan data data hasil analisis terlihat bahwa laba tertinggi Usaha Foto Copy Ayeng Komputer pada tahun 2009 didapatkan dengan menggunakan metode saldo menurun ganda yaitu sebesar $\mathrm{Rp}$. 16,341,950. Pada tahun 2010 laba tertinggi didapatkan jika menggunakan metode garis lurus yaitu sebesar Rp. 17,183,000 atau naik sebesar Rp. 847,050 dari tahun 2009. Pada tahun 2011 laba tertinggi kembali didapatkan jika menggunakan metode saldo menurun ganda yaitu sebesar Rp. 24,045,888 atau naik sebesar Rp.6,856,888 dari tahun 2010. Pada tahun 2012 laba tertinggi didapatkan jika menggunakan metode jumlah angka tahun yaitu sebesar Rp. 47,166,055 atau naik sebesar Rp.23,120,167 dari tahun 2011 dan Pada tahun 2013 laba tertinggi kembali didapatkan jika menggunakan metode jumlah angka tahun yaitu sebesar Rp. 54,574,382 atau naik sebesar Rp.7,408,273 dari tahun 2012
1. Hendaknya usaha foto Copy Ayeng Komputer menggunakan metode garis lurus dalam menghitung penyusutan aktiva tetapnya.

2. Hendaknya usaha foto Copy Ayeng Komputer menerapkan metode jumlah angka tahun pada tahun-tahun mendatang agar dapat menetukan seberapa besar laba usahanya.

\section{DAFTAR PUSTAKA}

Baridwan, Zaki, 2004, Intermediate Accounting, Edisi Kedelapan, Yogyakarta: BPFE

Earl K. Stice, James D. Stice, K. Fred Skousen. $2005 . \quad$ Intermediate Accounting. Bandung: Reksa Persada.

Eldon S. Hendriksen. 2000. Acconting Theory, Edisi Ke Lima. Southern Methodist University.

Harahap, Sofyan Syafri. 2002. Akuntansi Aktiva Tetap, Bumi Aksara: Jakarta.

\section{SARAN}

Berdasarkan kesimpulan yang telah dikemukakan, maka peneliti menyarankan: 